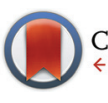

CrossMark \& click for updates

Cite this: Food Funct., 2016, 7, 239

Received 15th June 2015, Accepted 16th October 2015

DOI: $10.1039 / \mathrm{c} 5$ fo00718f

www.rsc.org/foodfunction

\section{The decrease in the IgG-binding capacity of intensively dry heated whey proteins is associated with intense Maillard reaction, structural changes of the proteins and formation of RAGE-ligands}

\author{
Fahui Liu, ${ }^{a}$ Małgorzata Teodorowicz, ${ }^{\text {b }}$ Martinus A. J. S. van Boekel, ${ }^{a}$ \\ Harry J. Wichers ${ }^{\mathrm{b}, \mathrm{c}}$ and Kasper A. Hettinga ${ }^{{ }^{a}}$
}

\begin{abstract}
Heat treatment is the most common way of milk processing, inducing structural changes as well as chemical modifications in milk proteins. These modifications influence the immune-reactivity and allergenicity of milk proteins. This study shows the influence of dry heating on the solubility, particle size, loss of accessible thiol and amino groups, degree of Maillard reaction, IgG-binding capacity and binding to the receptor for advanced glycation end products (RAGE) of thermally treated and glycated whey proteins. A mixture of whey proteins and lactose was dry heated at $130^{\circ} \mathrm{C}$ up to $20 \mathrm{~min}$ to mimic the baking process in two different water activities, 0.23 to mimic the heating in the dry state and 0.59 for the semi-dry state. The dry heating was accompanied by a loss of soluble proteins and an increase in the size of dissolved aggregates. Most of the Maillard reaction sites were found to be located in the reported conformational epitope area on whey proteins. Therefore the structural changes, including exposure of the SH group, $\mathrm{SH}-\mathrm{SS}$ exchange, covalent cross-links and the loss of available lysine, subsequently resulted in a decreased lgG-binding capacity (up to 33\%). The binding of glycation products to RAGE increased with the heating time, which was correlated with the stage of the Maillard reaction and the decrease in the IgG-binding capacity. The RAGE-binding capacity was higher in samples with a lower water activity (0.23). These results indicate that the intensive dry heating of whey proteins as it occurs during baking may be of importance to the immunological properties of allergens in cow's milk, both due to chemical modifications of the allergens and formation of AGEs.
\end{abstract}

\section{Introduction}

Food allergy in children is a serious health issue and an $18 \%$ increase in its prevalence from 1997 to 2007 has been reported. ${ }^{1}$ Cow's milk (CM) is one of the major food allergies in infants and young children, affecting $2 \%$ to $3 \%$ of the general population. Fortunately, most children allergic to CM develop tolerance at an early age, although $15 \%$ to $20 \%$ have a lifelong allergy. ${ }^{2}$ However, the mechanisms behind this tolerance development and the markers to predict it are still poorly understood.

The most popular treatment option for cow's milk allergy (CMA) has long been strict elimination of the allergens, and thus all milk and milk-containing products, from the diet. As

\footnotetext{
${ }^{a}$ Food Quality \& Design Group, Wageningen University \& Research Centre, 6700EV Wageningen, The Netherlands. E-mail: kasper.hettinga@wur.nl; Tel: +31317482401 ${ }^{b}$ Cell Biology and Immunology Group, Wageningen University and Research Centre, 6708WD Wageningen, The Netherlands

${ }^{c}$ Food and Biobased Research, Wageningen University and Research Centre, 6700 AA Wageningen, The Netherlands
}

the main source of proteins, calcium, phosphorus, vitamin $\mathrm{B}_{12}$ and vitamin $\mathrm{D}$, the elimination of milk from the diet likely presents nutritional disadvantages. In addition, long term avoidance of the allergen may increase the risk of an acute reaction upon the reintroduction or accidental ingestion of the allergens. ${ }^{3}$ Recently, it was reported that most of the children can tolerate intensively heated milk, in the form of baked products. ${ }^{4}$ The authors found that the children are more likely to become tolerant to unheated milk with the addition of intensively heated milk into their diets. In comparison to other allergen-specific approaches, the addition of intensively heated milk allergens probably represents a safer and effective approach to the immunomodulation of CMA. ${ }^{5}$ Research on the mechanism and for the establishment of the safety and efficacy of adding intensive heated milk proteins into the diets of CM allergic people is going on. But more research needs to be done before such foods can be used for clinical practice. ${ }^{6}$

Heat treatment is the most used process in the food industry. It induces structural changes as well as chemical modifications in milk proteins, which result in changes in the 
immune-reactivity and allergenicity. ${ }^{7}$ Heat treatment of milk allergens in solution was extensively studied, ${ }^{8}$ but only a limited number of studies have been done on dry heated milk $^{9,10}$. Dry heating is more close to the real conditions during the production of baked products. In the study of Enomoto et al. ${ }^{11} \beta$-lactoglobulin (BLG) was dry heated with maltopentaose at $85{ }^{\circ} \mathrm{C}$. Glycation and phosphorylation slightly affected the secondary structures of BLG, and the IgGbinding capacity was reduced by glycation. Besides, it was reported that the influence of dry heating and in-solution heating on structure modifications of proteins is different. ${ }^{12}$ In some cases, heat treatment reduces the allergenicity of allergens as a result of unfolding and aggregation. ${ }^{13}$ The temperature applied during in-solution heating is normally too low to eliminate the allergenicity of allergens, in particular when linear epitopes are involved. In the study of Sánchez-Monge et al. ${ }^{14}$ the antigenicity of $\beta$-lactoglobulin (BLG) was reduced but not eliminated when the samples were heated in solution at $80^{\circ} \mathrm{C}$ to $100{ }^{\circ} \mathrm{C}$. In some baked products used in studies on the induction of immune tolerance, it was shown that during baking some parts of the material turned into a semi-dry or dry state on reaching temperatures higher than $100^{\circ} \mathrm{C}$. It was, for example, reported that technological functional properties of egg white proteins were modified as a result of the formation of soluble aggregates linked with disulphide bonds and other covalent bonds when heated in such a semi-dry state. ${ }^{15}$ Besides, as conformational epitopes could become both either more accessible or more damaged by heat treatment, no general conclusion can be drawn on the influence of heat treatment on the antigenicity of allergens. In some cases, the antigenicity of allergens increased after heating, ${ }^{16}$ while in some other cases it was reduced. ${ }^{17}$

Furosine is the main stable Amadori compound in the early stage of Maillard reaction, and it is therefore considered as a good indicator of lysine damage upon heating of milk. ${ }^{18}$ In the intermediate and late stages of Maillard reaction, so-called advanced glycation end-products (AGEs) are generated as a result of the chemical reaction between reducing sugar and protein. Heat-processed foods are the main exogenous source of AGEs, which may be adsorbed from the gastrointestinal tract and exert their biological effects. ${ }^{19,20}$ Dry heating promotes the formation of dietary AGEs more than 10- to 100-fold above the unheated state of foods. ${ }^{21}$ These dietary AGEs increase the tissue level of AGEs and are thought to be involved in the aetiology of pathologies such as diabetes, atherosclerosis and cardiovascular diseases. ${ }^{22,23}$ The AGEs formed during food processing may influence human physiology via the receptor for advanced glycation end products (RAGE), which has been found in most key cell types to be linked to an immune response. ${ }^{24}$ Moreover, later studies showed that RAGE may play a role in the activation of many factors connected with acute and chronic immune responses, among others being the transcription factor NF-KB and some of its downstream target genes that are well-known regulators of the adaptive and innate immune systems. ${ }^{25}$ Moghaddam et al. found that the AGEs present on dry roasted prepared peanut proteins could target these proteins to antigen presenting cells. ${ }^{26}$ However, there is no data on the influence of intensive dry heating of milk proteins on sRAGE binding properties.

Changes in the IgG-binding capacity of whey proteins and formation of sRAGE binding ligands are thus expected after dry heating of whey proteins in the presence of lactose. The aim of this study was therefore to investigate the effect of intensive dry heating in two different water activities, 0.23 to mimic the heating in the dry state and 0.59 for the semi-dry state (as measured at room temperature), on the solubility, structural changes, degree of Maillard reaction, IgG-binding capacity of whey proteins and finally the production of AGEs and RAGE-binding ligands. It was also to provide a better molecular understanding of the finding that most of the children with CMA can tolerate intensively heated/baked milk and create a basis for studying the impact of Maillard reaction on the immunogenicity of whey proteins.

\section{Materials and methods}

\subsection{Materials}

The spray-dried WPC that was used in this study (Wheyco GmbH, Hamburg, Germany) was reported to contain $79.8 \%$ proteins, $4.2 \%$ water, $9.5 \%$ lactose and $5.8 \%$ fat. NuPAGE ${ }^{\circledR}$ $12 \%$ Bis-Tris Gels, running buffer, washing buffer and sample buffer for SDS-PAGE were provided by Life Technology (Carlsbad, USA). A molecular marker set of 9-170 kDa was obtained from Jena Bioscience (Jena, Germany). Antibodies used in ELISA analyses were provided by Abcam (Cambridge, UK). Anti-RAGE, the monoclonal mouse $\operatorname{IgG}_{2 \mathrm{~B}}$ human RAGE antibody (MAB11451) and the detection antibody were obtained from R\&D systems (Minneapolis, USA). The polyclonal goat anti-mouse HRP-conjugated antibody (P0447) was obtained from DAKO (Glostrup, Denmark). All the other chemicals were from Sigma-Aldrich (Zwijndrecht, The Netherlands).

\subsection{Preparation of samples}

Spray-dried WPC and lactose were dissolved in PBS pH 6.5 in a protein to lactose ratio of $1: 1.5(\mathrm{w} / \mathrm{w})$, which is similar to the protein to lactose ratio in milk. The solution was lyophilised. Two groups of such lyophilised samples $(10.6 \mathrm{~g})$ in plastic sample containers were stored in desiccators for two weeks at room temperature to obtain an $a_{\mathrm{w}}$ of 0.23 and 0.59 , respectively. Powders in a screw-cap test tube (Schott GL18) were heated at $130{ }^{\circ} \mathrm{C}$ for time periods of $5,10,20 \mathrm{~min}$ in a heating block (Labtherm Graphit, Liebisch, Germany). The samples were prepared in duplicate. Heated samples were put in an ice bath after the heat treatment to cool down immediately. Control samples $(0 \mathrm{~min})$ were not subjected to dry heating. Subsequently, all the powders were reconstituted in $50 \mathrm{ml}$ PBS, $\mathrm{pH}$ 7.4. After that, the solutions were centrifuged (rotor JA 25.50, Avanti Centrifuge J-26 XP, Beckman Coulter, USA) at $10000 \mathrm{~g}$ for $30 \mathrm{~min}$ to separate the insoluble material from the soluble material. The resulting pellets were washed twice and centrifuged again. Finally, $70 \mathrm{~mL}$ solution was obtained for 
each sample. Ten $\mathrm{mL}$ of the dissolved sample was centrifuged again using an ultra-centrifugal device (Pall Life Science, Ann Arbor, USA) with a cut-off of $3 \mathrm{kDa}$ to concentrate the samples and filter out the compounds with a molecular weight lower than $3 \mathrm{kDa}$. The dissolved protein concentration of all the samples was measured by the BCA method. ${ }^{27}$

\subsection{Sodium dodecyl sulfate polyacrylamide gel electrophoresis (SDS-PAGE) analysis of conjugates}

SDS-PAGE was performed under non-reducing conditions. Two $\mu \mathrm{L}$ sample was diluted in $5 \mu \mathrm{L} 4 \times$ concentrated sample buffer and $15 \mu \mathrm{L}$ MilliQ water. Then the mixture was centrifuged at $2000 \mathrm{rpm}$ for $1 \mathrm{~min}$ and heated at $70{ }^{\circ} \mathrm{C}$ in a heating block (Labtherm Graphit, Liebisch, Germany) for $10 \mathrm{~min}$. Samples were then loaded onto $12 \%$ Bis-Tris Gels. To show the heatinduced decrease in the amount of soluble proteins, the protein concentration was not adjusted to the same level after heat treatment, but was based on the same amount of protein that was present before heating $\left(1 \mathrm{mg} \mathrm{mL}^{-1}\right)$. Gels were run at $200 \mathrm{~V}$ and stained with Coomassie Blue R-250, followed by destaining with washing buffer. A prestained protein marker (9-170 kDa) was used for molecular weight calibration. The scanned gels were analysed by Image Lab version 4.1 (BioRad).

\subsection{Particle size measurements}

The particle size distribution of all the samples was measured using a Malvern Hydro 2000sm (Malvern Instruments, Malvern, UK). The determination of particle size distribution was based on the Mie scattering theory. ${ }^{28}$ Size measurements were recorded as median diameters $D_{0.5}$ and $D_{0.9}$ of triplicate measurements, where $50 \%$ and $90 \%$ of the particles are smaller than the size indicated, respectively. The instrument was set to measure the sample at a rate of 3000 snaps (or counts) per second. To avoid multiple scattering, the samples were added into the dispersion unit till the obscuration value reached between $10 \%$ and $20 \%$.

\subsection{Measurement of accessible thiol groups}

The quantification of accessible thiol content was performed according to the Ellman method. ${ }^{29}$ All the samples were prepared at the same protein concentration of $1 \mathrm{mg} \mathrm{mL}^{-1}$. Then $10 \mu \mathrm{L}$ of the sample was mixed well with $990 \mu \mathrm{L}$ of $0.1 \mathrm{mM}$ 5,5'-dithiobis(2-nitrobenzoate) (DTNB) reagent. Samples with only the DTNB reagent were used as blank. Optical absorbance was measured at $412 \mathrm{~nm}$ for each sample after incubation at room temperature for $5 \mathrm{~min}$.

\subsection{Determination of free amino groups}

The $o$-phthaldialdehyde (OPA) method was applied for quantifying free amino groups according to the method of Nielsen et $a l .{ }^{30}$ with modifications. The dissolved protein samples were diluted to a protein concentration of $0.32 \mathrm{mg} \mathrm{mL}^{-1}$ in $\mathrm{PBS} \mathrm{pH}$ 7.4. A freshly prepared OPA reagent was mixed with diluted samples in a ratio of $20: 3(\mathrm{v} / \mathrm{v})$, followed by incubation at room temperature for $20 \mathrm{~min}$. The absorbance was measured at
$340 \mathrm{~nm}$ against a control containing PBS and the OPA reagent. All the samples were measured in duplicate. The amount of the free amino groups in unknown samples was calculated according to a standard curve made using 0.78 to $2.5 \mathrm{mM}$ L-leucine.

\subsection{Determination of the degree of Maillard reaction}

The colour of the dry heated whey protein and lactose mixtures was measured using a ColorFlex spectrophotometer (Hunter Associates Laboratory Inc., Reston, VA). The system was calibrated using black, white and green plates. The results were recorded as $L$ (lightness, $0=$ black; $100=$ white), $a$ (red to green, $+a=$ red; $-a=$ green) and $b$ (yellow to blue, $+b=$ yellow; $-b=$ blue). The colour difference index $E$ was calculated according to the equation: $\Delta E=\left(\Delta L^{2}+\Delta a^{2}+\Delta b^{2}\right)^{1 / 2} \cdot{ }^{31}$

Determination of furosine was performed with an RP-HPLC system using an RP-8 furosine dedicated column $(5 \mu \mathrm{m}, 250 \times$ $4.6 \mathrm{~mm}$, Grace, Deerfield, USA) according to the method of Resmini et al. ${ }^{32}$ The heated and control samples were hydrolysed with $4 \mathrm{~mL}$ of $7.95 \mathrm{~N} \mathrm{HCl}$ at $110{ }^{\circ} \mathrm{C}$ for $23 \mathrm{~h}$ in a screw-cap test tube (Schott GL18). The hydrolysates were filtered through medium-grade filter paper and transferred to new tubes. A portion of the filtrate was further purified by solid phase extraction (cartridge C18-E, phonomenex, Aschaffenburg, Germany) pre-wetted with $2 \mathrm{~mL}$ of $0.3 \%$ acetic acid. Furosine was eluted with $3 \mathrm{~mL}$ of $3 \mathrm{~N} \mathrm{HCl}$ and collected in HPLC vials. Then the furosine standard (Poly Peptide group, Strasbourg, France) and purified samples were applied to the Dionex Ultimate 3000 HPLC system with a RS Diode Array UV detector at $280 \mathrm{~nm}$. The column was eluted with solvent A containing $0.4 \%$ acetic acid in MilliQ water at a flow rate of $1.2 \mathrm{~mL} \mathrm{~min}^{-1}$; furosine was eluted by solvent $\mathrm{B}$ which contains $0.3 \%$ potassium chloride in solvent $A$ at $22-24 \mathrm{~min}$. The elution gradient was: $0-8.5 \mathrm{~min} 0 \%$ solvent $\mathrm{B}, \mathbf{8 . 5}-16.5 \mathrm{~min}$ multistep gradient from $0 \%$ to $50 \%$ solvent $\mathrm{B}, 16.5-19.0 \mathrm{~min} 50 \%$ solvent $\mathrm{B}$, 19.0-20.5 min multistep gradient from $50 \%$ to $0 \%$ solvent $\mathrm{B}$, 20.5-32.0 min 0\% solvent B.

After acid hydrolysis of milk proteins, the protein-bound lactulosyl-lysine is released as $40 \%$ Lys and $32 \%$ furosine. ${ }^{33}$ Because these products are released in a constant ratio, the amount of blocked lysine in the early stage can be calculated from the amount of furosine (mg per $100 \mathrm{~g}$ protein) and the total lysine (mg per $100 \mathrm{~g}$ protein) using the formula as follows: ${ }^{34}$

$$
\% \text { blockage due to Amadori product }=\frac{1.24 \text { furosine }}{\text { total lysine }} \times 100
$$

\subsection{Determination of the IgG-binding capacity by enzyme- linked immunosorbent assay (ELISA)}

Non-competitive ELISA was performed according to a method previously reported. ${ }^{35}$ Briefly, heated and unheated whey protein samples were dissolved in coating buffer at a protein concentration of $5 \mu \mathrm{g} \mathrm{mL} \mathrm{m}^{-1}$. Then $100 \mu \mathrm{L}$ of these diluted samples was added to a 96 wells plate; coating buffer alone was used as the negative control. The plate was incubated at $4{ }^{\circ} \mathrm{C}$ overnight to coat the wells with antigens. After removal of the solution, each well was washed 3 times with $250 \mu \mathrm{L}$ of 
PBS-Tween (PBST). Then all the wells were saturated at $37^{\circ} \mathrm{C}$ for $1 \mathrm{~h}$ with $1 \%$ gelatin in coating buffer. Plates were washed with PBST and $100 \mu \mathrm{L}$ of a rabbit anti-whey protein IgG antibody diluted to 1 : 10000 in PBS pH 9.6 was added and incubated $1 \mathrm{~h}$ at $37^{\circ} \mathrm{C}$. A peroxidase conjugated goat anti-rabbit IgG antibody diluted to $1: 10000$ in PBS was added to each well after the plates were washed three times with PBST. Then $0.4 \mathrm{mg}$ per $\mathrm{mL}$ of o-phenylenediamine (OPD) in $50 \mathrm{mM}$ citrate buffer $\mathrm{pH} 5.5$ containing $0.1 \%(\mathrm{v} / \mathrm{v})$ of $30 \%$ hydrogen peroxide was added to each well $(100 \mu \mathrm{L}$ per well), followed by $15 \mathrm{~min}$ of incubation at $37{ }^{\circ} \mathrm{C}$. The reaction was stopped by addition of $50 \mu \mathrm{L}$ of $2 \mathrm{M}$ $\mathrm{H}_{2} \mathrm{SO}_{4}$. The absorbance was measured at $492 \mathrm{~nm}$.

\subsection{RAGE binding assay}

The competition ELISA-based RAGE binding assay was used to measure the binding between the sRAGE receptor and dry heated samples. The specificity was tested by creating competition between a known high affinity ligand coated on the plate and the possible ligand-dry heated samples. The transparent ELISA plates (Geiner Bio-One, cat $\mathrm{nr}$ 655061) were coated with Glycated 90 in $1.5 \mathrm{mM}$ of sodium carbonate buffer $\mathrm{pH} 9.6$ overnight at $4{ }^{\circ} \mathrm{C}$. Next day the plate was washed 3 times with PBS containing $0.05 \%(\mathrm{v} / \mathrm{v})$ Tween-20 and the plate was blocked with $3 \%$ BSA for 2 hours at room temperature. During the blocking, the pre-incubation of samples $(0.5,5,50$, $500 \mu \mathrm{g} \mathrm{mL}{ }^{-1}$ ) with sRAGE (recombinantly produced in E. coli. Biovendor RD172116100, $27.4 \mathrm{nM}$ ) was performed on a polystyrene 96-well plate (Nunc). Both the sRAGE and samples were dissolved in $1.5 \%$ BSA and $0.025 \%$ Tween-20 in PBS. The positive control (maximal signal) was sRAGE incubated without a ligand in dilution buffer. Incubation was performed for 45 minutes at $37^{\circ} \mathrm{C}$. After blocking, the coated ELISA plate was washed 3 times and then the pre-incubation mixture was added ( $80 \mu \mathrm{L}$ per well) followed by 1 hour of incubation at $37^{\circ} \mathrm{C}$. The plate was washed 3 times after which the anti-RAGE antibody (monoclonal Mouse $\operatorname{IgG}_{2 \mathrm{~B}}$ human RAGE antibody MAB11451; $23.3 \mathrm{nM}$ ) was added and incubated for 30 minutes in a shaker at room temperature. After washing 4 times the detection antibody (polyclonal goat anti-mouse HRP-conjugated P0447; 1 : 1000) was added and incubated for 30 minutes in a shaker at room temperature. The plate was washed 4 times and the TMB substrate (3,3',5, $5^{\prime}$-tetramethylbenzidine) was added and incubated for 15 minutes. The colouring was stopped using $2 \% \mathrm{HCl}$. The plate was read using the Filtermax F5 at $450 \mathrm{~nm}$ with $620 \mathrm{~nm}$ as the reference. The percentage of inhibition was determined using the follow formula: $\left(\frac{\text { ODsRAGE }- \text { ODsample }}{\text { ODsRAGE }}\right) \times 100$, with the average ODs of SRAGE without the competition agent as a maximal signal.

\section{Results \& discussion}

\subsection{Characterization of dry heated whey proteins}

Analysis of PBS pH 7.4 soluble protein concentrations by the BCA method showed that the amount of soluble proteins
Table 1 Formation of insoluble material and furosine after dry heating at $130{ }^{\circ} \mathrm{C}$ for different periods of time. Results are means of two independent experiments \pm standard deviation. The blocked lysine due to the formation of an Amadori product (\%) was calculated from the amount of furosine

\begin{tabular}{llllll}
\hline $\begin{array}{l}\text { Heating } \\
\text { time } \\
(\mathrm{min})\end{array}$ & $\begin{array}{l}\text { Initial } \\
a_{\mathrm{w}}\end{array}$ & $\begin{array}{l}\text { Soluble } \\
\text { protein } \\
\text { recovery }\end{array}$ & $\begin{array}{l}\text { Insoluble } \\
\text { material } \\
(\mathrm{g})\end{array}$ & $\begin{array}{l}\text { Furosine } \\
\text { (mg per } \\
100 \mathrm{~g} \text { protein })\end{array}$ & $\begin{array}{l}\text { Blocked } \\
\text { lysine } \\
(\%)\end{array}$ \\
\hline 0 & 0.23 & $97.9 \%$ & $0.1 \pm 0.0$ & $30.8 \pm 6.9$ & $0.5 \pm 0.1$ \\
5 & 0.23 & $85.4 \%$ & $0.6 \pm 0.3$ & $278.3 \pm 39.5$ & $4.5 \pm 0.4$ \\
10 & 0.23 & $67.9 \%^{*}$ & $2.7 \pm 0.8$ & $184.8 \pm 41.8$ & $3.0 \pm 0.5$ \\
20 & 0.23 & $11.2 \% *$ & $6.4 \pm 0.1$ & $83.2 \pm 5.5$ & $1.4 \pm 0.3$ \\
0 & 0.59 & $97.4 \%$ & $0.1 \pm 0.0$ & $42.2 \pm 0.5$ & $0.7 \pm 0.0$ \\
5 & 0.59 & $87.6 \%$ & $0.3 \pm 0.1$ & $294.8 \pm 19.6$ & $4.8 \pm 0.3$ \\
10 & 0.59 & $78.4 \%^{*}$ & $1.8 \pm 0.1$ & 241.6 & 2.0 \\
20 & 0.59 & $17.7 \%^{*}$ & $6.4 \pm 0.1$ & $109.6 \pm 5.0$ & $1.8 \pm 0.1$
\end{tabular}

* Significant at $p<0.05$.

decreased with the heating time (Table 1). The highest decrease in protein concentration was observed between 10 and 20 min of dry heating. More than $80 \%$ of the proteins existed as insoluble aggregates after being heated for $20 \mathrm{~min}$ at $130{ }^{\circ} \mathrm{C}$. As expected, the amount of insoluble material increased with the heating time in both groups of the samples with an initial $a_{\mathrm{w}}$ of 0.23 and 0.59 . Samples with $a_{\mathrm{w}} 0.23$ showed a higher loss in soluble proteins versus the samples with $a_{\mathrm{w}}$ 0.59. In the unheated samples, the soluble protein recovery reached over $97 \%$. It has been previously shown that the denatured proteins first convert into soluble aggregates and then into insoluble aggregates during dry heating. ${ }^{10}$ Table 1 indicates that the conversion into insoluble aggregates took place between 10 and 20 min of dry heating in this study.

SDS-PAGE under non-reducing conditions of dry heated whey proteins (Fig. 1) demonstrated that the amount of $\beta$-lactoglobulin (BLG)- and $\alpha$-lactalbumin (ALA)-dimers increased in the samples heated for 5 and $10 \mathrm{~min}$. The electrophoretic mobility of monomeric and dimeric whey proteins decreased in heated samples; no bands with molecular weights corresponding to non-heated BLG were found for all 3 time points of heat treatment. This is in agreement with the results reported by Li et $a l{ }^{36}$ which also showed an increase in the molecular mass of BLG and ALA. This may have resulted from the conjugation of whey protein and lactose. ${ }^{37}$ In the samples with $a_{\mathrm{w}}$ of 0.23 , the amount of soluble monomeric proteins and soluble aggregates decreased faster than those of samples with $a_{\mathrm{w}}$ of 0.59 , confirming the results of protein concentration as measured by BCA (Table 1$)$.

\subsection{Structural consequences of dry heating on whey proteins}

3.2.1 Particle size distribution. Laser light scattering was used to study the particle size distribution of the heated and unheated soluble samples. Soluble aggregates were formed during the dry heat treatment. As shown in Fig. 2, no considerable changes of the mean particle size $\left(d_{50}\right)$ were observed in the unheated samples and samples heated for 5 and $10 \mathrm{~min}$. 


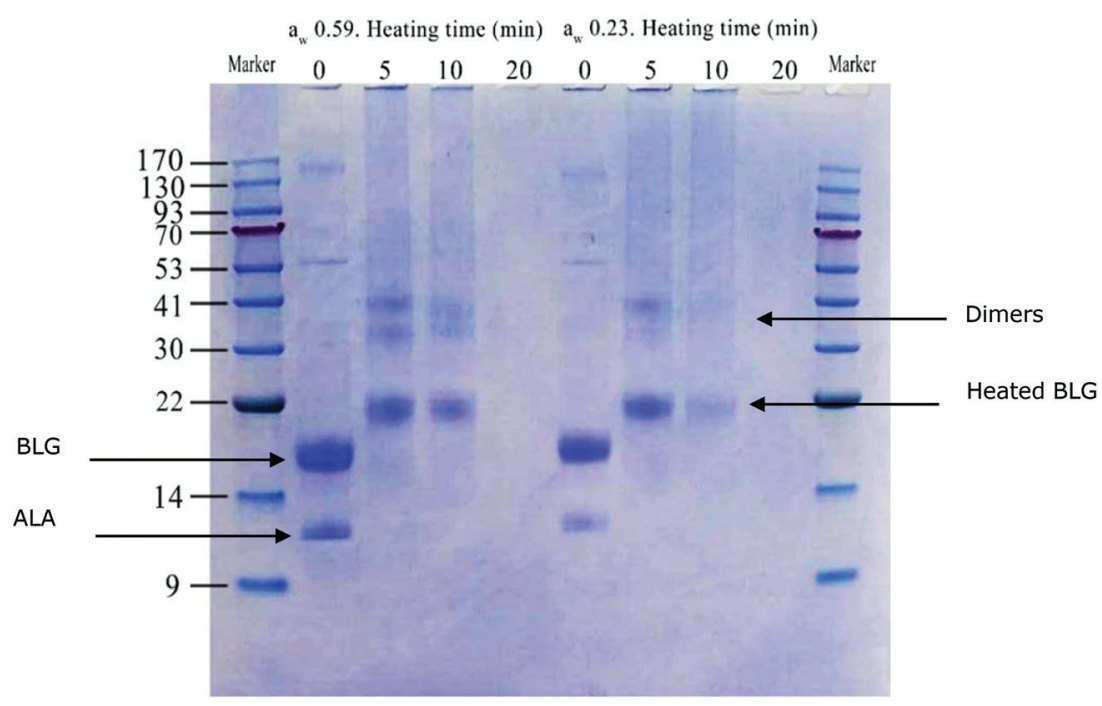

Fig. 1 SDS-PAGE profile of dry heated whey proteins (soluble fraction at pH 7.4) under non-reducing conditions. A marker with a molecular weight range of 9-170 kDa was used; the samples were prepared in duplicate. Whey protein samples with a water activity of 0.23 and 0.59 were heated for $5,10,20 \mathrm{~min}$ at $130^{\circ} \mathrm{C}$. Non-heated samples $(0 \mathrm{~min}$ ) were used as controls.
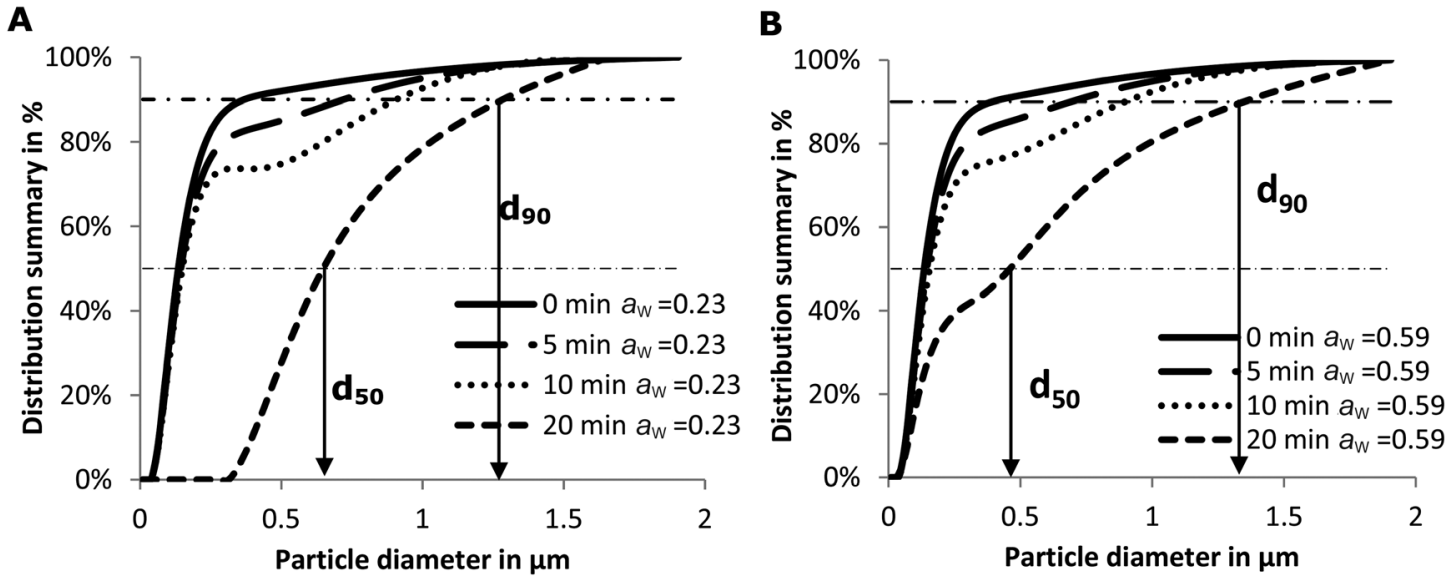

Fig. 2 Average effects of the dry heating time at $130{ }^{\circ} \mathrm{C}$ on particle size distribution of soluble whey proteins, based on triplicate measurements. A: initial $a_{w}=0.23$, B: initial $a_{w}=0.59$.

Larger aggregates were formed in the samples that were heated for a longer time. Literature data show that for in-solution heating, a higher whey protein concentration resulted in a larger aggregate size, whereas for dry state heating, formation of aggregates was mainly affected by the diffusion-controlled interactions between proteins or protein and lactose. ${ }^{10}$ The $d_{50}$ reached about $0.65 \mu \mathrm{m}$ in samples with $a_{\mathrm{w}} 0.23$ and $0.49 \mu \mathrm{m}$ in samples with $a_{\mathrm{w}} 0.59$ after $20 \mathrm{~min}$ of heating at $130{ }^{\circ} \mathrm{C}$. The higher particle size and lower soluble protein concentration in samples with $a_{\mathrm{w}} 0.23$ indicated that the lower $a_{\mathrm{w}}$ favours the denaturation and Maillard reaction of whey proteins. This is in line with the SDS-PAGE result, in which more soluble aggregates were observed in the heated samples with $a_{\mathrm{w}} 0.23$ (Fig. 1). Aggregate size has previously been shown to increase with heating temperature, with particle sizes reaching $1 \mu \mathrm{m}$ after heating at $148{ }^{\circ} \mathrm{C}$ for $15 \mathrm{~min}$. But when a whey protein solution was heated at $90{ }^{\circ} \mathrm{C}$, a mean size of only $0.13 \mu \mathrm{m}$ was reached, even after 35 min of heating. ${ }^{8}$

3.2.2. Quantification of sulfhydryl groups. The amount of accessible $\mathrm{SH}$ groups during heat treatment depends on two competing processes: exposure of the masked $\mathrm{SH}$ groups and loss of accessible $\mathrm{SH}$ by oxidation. As shown in Fig. 3A, at the early stage of dry heating, the concentration of accessible $\mathrm{SH}$ groups increased in both groups of the samples at an $a_{\mathrm{w}}$ of 0.23 and 0.59 . Thermal induced exposure of masked sulfhydryl groups probably dominated in this stage. Heating at $130^{\circ} \mathrm{C}$ for more than $5 \mathrm{~min}$ resulted in a decrease in the amount of accessible $\mathrm{SH}$ groups most likely due to the observed 

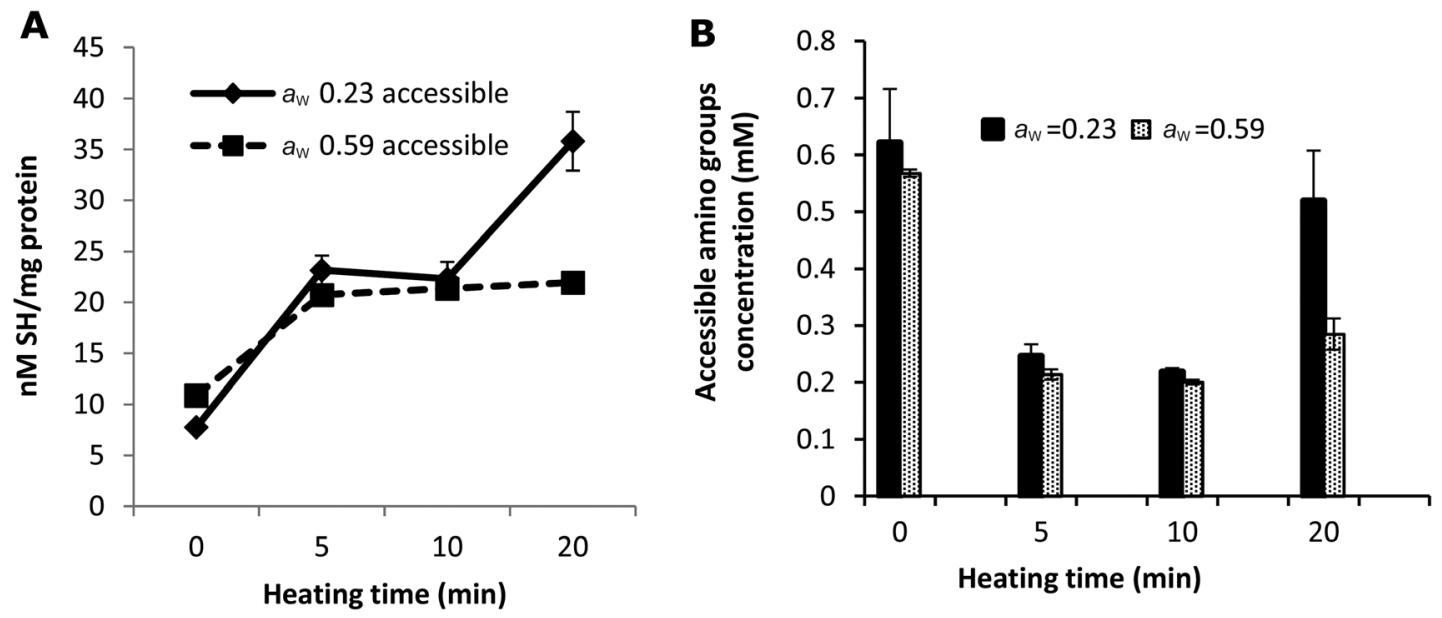

Fig. 3 Comparison of accessible SH (A) and amino (B) groups in the samples with $a_{w}$ of 0.23 and 0.59 . The protein concentration of all the samples was adjusted to $0.96 \mathrm{mg} \mathrm{ml}^{-1}$. The concentration of accessible amino groups was measured by the OPA method. Error bars represent standard deviations of duplicate measurements.

formation of aggregates which may have formed by oxidation of $\mathrm{SH}$. The net balance of exposure and aggregations caused the accessible $\mathrm{SH}$ groups to remain stable in the samples with $a_{\mathrm{w}} 0.23$ and decrease slightly in the samples with $a_{\mathrm{w}} 0.59$ between time points 5 and 10. The amount of accessible $\mathrm{SH}$ groups increased again in the samples with $a_{\mathrm{w}} 0.23$ after $20 \mathrm{~min}$ of heating. Similar results were reported for samples heated under wet conditions. ${ }^{38}$ This indicates that with an increase in the applied heating temperature, the thiol groups become exposed as a result of the molecular rearrangement of the aggregates. The exposed thiol groups interact with other molecules; small oligomers are subsequently formed through disulfide bonds. When the concentration of oligomers reaches a certain level, the so-called primary aggregates start to form.

\subsection{Degree of Maillard reaction}

3.3.1. Colour development. Some indicators of the degree of Maillard reaction, such as furosine and HMF, are colourless, and therefore cannot be reflected in the $L$ value (lightness). The brown pigments are difficult to analyse chemically because of the complexity of their structures and low solubility due to a high molecular weight. ${ }^{39}$ However, as an indicator of the degree of Maillard reaction, the $b$ value (yellowness) reflects the progress of the late-stage reaction. ${ }^{40}$ In this study, the lightness $(L)$ of the dry heated samples decreased upon heating for 0-10 $\mathrm{min}$, due to the formation of brown pigments. After 20 min of dry heating, a slight increase in $L$ was observed for both groups of samples with initial $a_{\mathrm{w}} 0.23$ and 0.59 . The trend of the change in lightness corroborated with that for accessible amino groups. Lactose reacts with the $\varepsilon$-amino groups of whey proteins to form chromophoric, reactive side chains that eventually crosslink with other protein moieties to form an insoluble brown material, which increases with the heating time (Table 1). This may also explain the loss of accessible amino groups and the increase of soluble and insoluble coloured materials. The increase in $a$-value also correlated with the loss of the $\varepsilon$-amino group of lysine.

In this study, the samples were intensively dry heated. Consequently, the thermal degradation of sugars led to the formation of brown-coloured products. The amount of coloured insoluble Maillard reaction products increased with the heating time (Table 1). This increase in insoluble coloured material may explain the increase in lightness in the soluble fraction of the samples heated for $20 \mathrm{~min}$ at $130{ }^{\circ} \mathrm{C}$.

3.3.2. Quantification of furosine and accessible amino groups. Furosine, a marker of Amadori products produced in the early stage of the Maillard reaction, was already detected in unheated samples (Table 1). Furosine may have been formed during the production of WPC and/or the storage of the sample for adjusting $a_{\mathrm{w}}$. The amount of furosine increased after 5 min of dry heating at $130{ }^{\circ} \mathrm{C}$. A subsequent decrease was observed in both groups of the samples, with $a_{\mathrm{w}} 0.23$ and 0.59 (Table 1). After such intense heating, the degradation of Amadori compounds in the advanced stages of the Maillard reaction would result in the subsequent decrease of furosine. The amount of furosine detected in the samples heated at different $a_{\mathrm{w}}$ correlated with the solubility of proteins after heating (Table 1). The formation of insoluble aggregates as an effect of advanced stages of the Maillard reaction, as seen after 20 minutes of heating, may also explain the decrease of the furosine content in these samples. The decrease in the amount of furosine in samples with $a_{\mathrm{w}} 0.23$ was faster than that in samples with $a_{\mathrm{w}} 0.59$, which indicates that the Maillard reaction advances more easily to the advanced stage at a lower $a_{\mathrm{w}}$.

The amount of blocked lysine due to the Amadori product, which results from a reaction between the free $\varepsilon-\mathrm{NH}_{2}$ group of lysine and lactose in the early stages of the Maillard reaction, was calculated based on the amount of furosine (Table 1). However, the amount of blocked lysine originating from the advanced stages cannot be calculated from these results. The 
$o$-phthaldialdehyde (OPA) method was therefore used to measure the total loss of accessible $\mathrm{NH}_{2}$ groups, as a marker for the total loss of lysine. Fig. 3B shows that additional blockage takes place indicating that the Maillard reaction proceeded to advanced stages resulting in changes in the structure of whey proteins.

The quantity of accessible amino groups reflects the degree of glycation and aggregation of whey proteins. Probably as a result of protein aggregation, as evidenced in Fig. 2, the number of accessible amino groups decreased with the heating time in all the samples heated for 5 and $10 \mathrm{~min}$ (Fig. 3B). There are many possible explanations for the loss of accessible amino groups. The attachment of lactose to whey proteins involves accessible $\mathrm{NH}_{2}$ groups in the Maillard reaction between the proteins and lactose, which leads to the formation of Amadori products. This was confirmed by the results of furosine analysis (Table 1). The amount of accessible amino acids increased in the samples heated at $130{ }^{\circ} \mathrm{C}$ for $20 \mathrm{~min}$, especially in the samples with a water activity of 0.23 . Similar to the explanation of the result of accessible $\mathrm{SH}$ measurement as shown in Fig. 3A, this could also be the result of the unfolding and molecular rearrangement of the proteins and aggregates. In addition, the increase in the concentration of accessible $\mathrm{NH}_{2}$ groups in the samples heated for $20 \mathrm{~min}$ may be explained by the breakdown of proteins and Maillard products in the advanced stages of the Maillard reaction, ${ }^{41}$ as the OPA reacts readily with the $\mathrm{N}$-terminal amino groups resulting in the breakdown of whey proteins and Maillard products.

\subsection{IgG-binding capacity of whey proteins}

ALA and BLG are major allergens in whey. The reported IgG epitopes of ALA are AA 7-18, AA 51-61 and AA 89-108. ${ }^{42}$ As shown in Fig. 4A, 67\% (8 out of 12) of the lysines in ALA are in these epitopes. On BLG, AA 1-16, AA 51-64, AA 67-96 and AA 129-156 are the IgG-binding epitopes. As shown in Fig. 4B, $80 \%$ (12 out of 15 ) of the lysines in BLG are located in these IgG binding areas. Consequently, the damage to lysine residues during the Maillard reaction likely resulted in structural changes of epitopes on whey proteins, and may thus influence the IgG-binding capacity of whey proteins. To test this, noncompetitive ELISA was performed.

The decrease in the IgG-binding capacity of whey proteins after heating in solution was reported previously. ${ }^{43,44}$ These authors explained their observations by the shielding effects of epitopes owing to the Maillard reaction. When the heating temperature is above $90{ }^{\circ} \mathrm{C}$, conformational epitopes may be destroyed by the aggregation between whey proteins (disulphide exchange) or by the advanced Maillard reaction. On the other hand, hidden conformational epitopes on whey proteins may be exposed at temperatures higher than $65^{\circ} \mathrm{C}$ as a result of protein unfolding, which may coincide with the exposure of hidden $\mathrm{SH}$ groups thereby increasing the amount of accessible $\mathrm{SH}$ groups (Fig. 3A). In addition, linear epitopes may also become exposed and be involved in the aggregation of the allergen. ${ }^{45}$ Consequently, the destruction and exposure
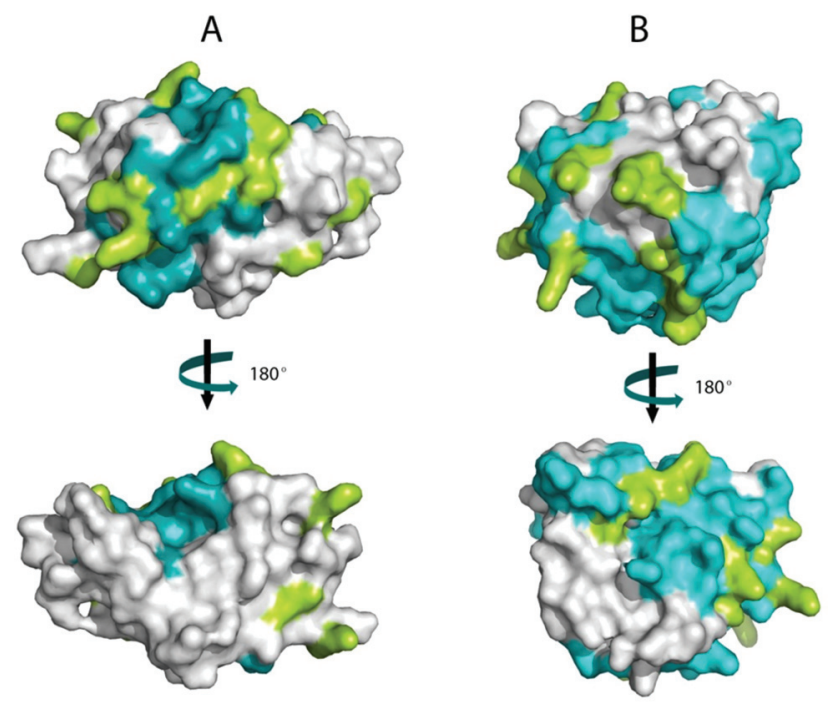

Fig. 4 Identification of IgG epitopes and lysines on the surface of bovine $\beta$-lactoglobulin (BLG) and $\alpha$-lactalbumin (ALA). The surfaces of ALA (A) and BLG (B) showing two views of the proteins, rotated $180^{\circ}$ about the vertical axis. The conformational structures were obtained from the Protein Data Bank (PDB) and displayed in PyMOL v0.99. The epitopes are coloured cyan, and the lysines are coloured Limon.

of both conformational and linear epitopes determines the overall IgG-binding capacity of whey proteins. As shown in Fig. 5, the IgG-binding capacity of whey proteins decreased with the heating time in both groups of samples with different $a_{\mathrm{w}}$. After heating at $130{ }^{\circ} \mathrm{C}$ for $20 \mathrm{~min}$, the IgG-binding capacity decreased to about $67 \%$ of that of the unheated samples. These results indicate that heat-induced destruction of epitopes determined the IgG-binding capacity of whey proteins under dry and semi-dry heating conditions, which is similar to what was previously only shown for proteins in a wet system. ${ }^{45}$

Moreover, the Maillard reactions initiate changes in the hydrophilic-hydrophobic potential of heat-treated proteins. ${ }^{46}$ As the hydrophobic properties of proteins have previously been shown to play an important role in protein-protein (proteinantibody) interactions, ${ }^{47}$ the observed decrease in IgG binding may thus also result from changes in hydrophilic/hydrophobic areas and net charge at the protein surface caused by attached sugar moieties.

Another factor that may influence IgG binding is the formation of aggregates. Spiegel reported that more compact particles are formed at temperatures above $90{ }^{\circ} \mathrm{C}$ under wet conditions. ${ }^{48}$ Antibodies can only reach the epitopes on the surface of these particles. ${ }^{8}$ As a result, the IgG-binding capacity decreases with the heating time and hence with particle size (Fig. 5B). In addition, the epitopes on the surface may simultaneously be destroyed in two ways: by aggregation of proteins and by a Maillard reaction with lactose. This may result in the loss of accessibility of some epitopes initially located on the surface of whey proteins (Fig. 4). Subsequently, the IgGbinding capacity of the PBS soluble allergens decreases with the increase of particle size (Fig. 5B). Similar results were 
A

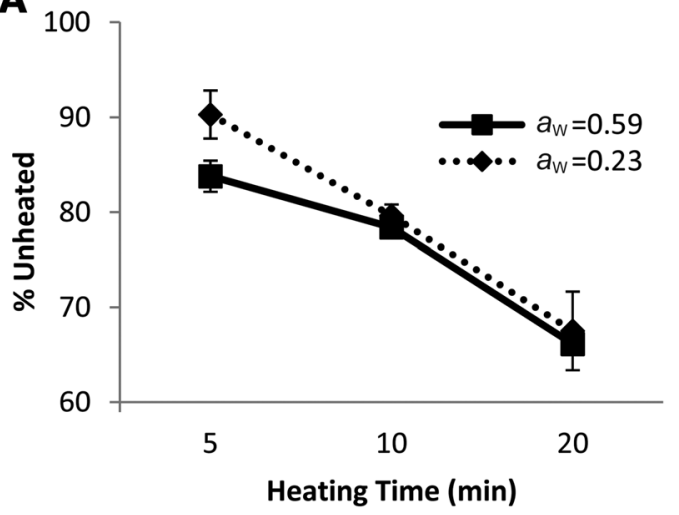

B

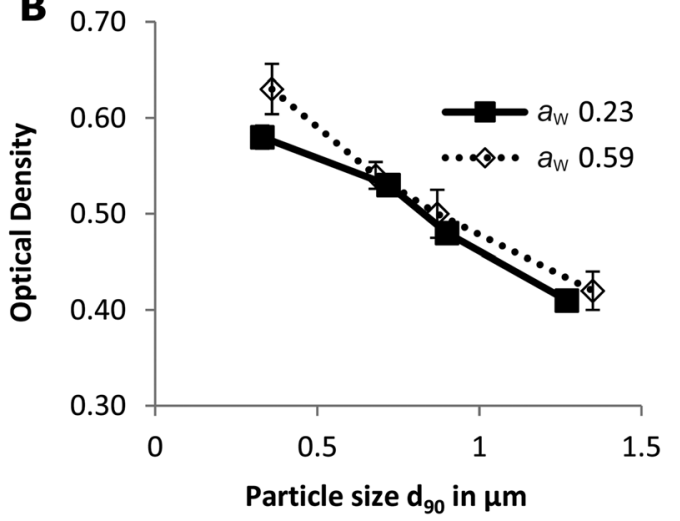

Fig. 5 The IgG-binding capacity of heated whey proteins (A) and its correlation with particle size (B). The lgG-binding capacity is expressed as the percentage of signals obtained by noncompetitive ELISA on unheated whey protein samples. Error bars represent standard deviations of triplicate measurements.

reported on peanut allergen Ara $\mathrm{h} 1$ and hazelnut allergen Cor a11. ${ }^{49}$ A significant decrease in the IgE binding capacity of Ara h1 and Cor a11 roasted with glucose was observed, which was accompanied by an increase in their particle size.

\subsection{Formation of RAGE-binding ligands}

The binding between SRAGE and its ligand was dose-dependently inhibited by glycated whey protein samples (Fig. 6A and B). As presented in Fig. 6C and D, the unheated sample is not able to inhibit RAGE-ligand binding while up to $90 \%$ of inhibition was observed for dry-heated whey proteins. After $10 \mathrm{~min}$ of dry heating to achieve a concentration of $50 \mu \mathrm{g} \mathrm{ml}{ }^{-1}$, the ability of heated whey proteins (both $a_{\mathrm{w}} 0.23$ and 0.59 ) to bind to RAGE was higher than that of the positive control samples (amyloid beta). The data suggest that more RAGE binding ligands were formed in the samples with $a_{\mathrm{w}} 0.23$ or the formed Maillard reaction products/aggregates have a higher RAGE binding potential than products of heating with $a_{\mathrm{w}} 0.59$. Furosine was already detected in the unheated samples due to either the production process of WPC or the storage of the samples at room temperature for $a_{\mathrm{w}}$ adjustment (Table 1); however, the unheated sample did not show any RAGE binding activity, indicating that no advanced Maillard reaction had yet occurred. Less PBS-soluble proteins, as shown in Fig. 1, and larger aggregates in samples with $a_{\mathrm{w}} 0.23$ (Fig. 2) indicate that intensive dry heating at $a_{\mathrm{w}} 0.23$ favoured the aggregation and Maillard reaction of the samples, which correlated with the sRAGE-binding results that showed more ligands were present in the sample heated at this water activity. In humans, there are two types of RAGE receptors, a soluble form (sRAGE) and a membrane-bound form. In this study, the ELISA based RAGE-binding assay was performed to analyse the binding ability of BLG-derived Maillard reaction products to sRAGE. The low levels of this form of the receptor are normally present in human plasma and may be bound to the food derived AGEs which have been absorbed in the gut and have gotten to the bloodstream. Compared to the interactions between AGEs and cell surface RAGE, the binding of sRAGE and AGEs offers protective effects as AGE inhibitors. ${ }^{23,50}$ Two distinct mechanisms are known for the generation of the soluble form of the RAGE receptor. First, alternative splicing can lead to the removal of the transmembrane or cytosolic domains of the membrane form of the receptor. Secondly, metalloproteases ADAM10 and MMP9 are able to cleave RAGE in the extracellular domain close to the transmembrane helix. Both mechanisms can form the sRAGE that binds ligands with a similar affinity as the membrane bound receptor. ${ }^{25,51,52}$

The interaction between RAGE and the AGEs may be one of the mechanisms explaining the immunomodulatory properties of AGEs. Two unrelated studies showed the binding between RAGE and AGEs on antigen presenting cells. Hilmenyuk and co-workers found that immature dendritic cells (DC) express RAGE stronger compared to mature DCs. Moreover, an enhanced expression of RAGE on the immature DCs was observed after exposure to AGEs. ${ }^{53}$ In a recent study, Mueller and others determined the binding of the Maillard reaction products present on raw peanut and oven-roasted peanut towards IgE and RAGE. The authors showed that RAGE interacts with the AGE modified recombinant peanut allergen Ara h1 and not with the unmodified recombinant Ara h1.$^{54}$ These outcomes are in line with our findings. We did not observe an interaction of unheated whey proteins with SRAGE. The SRAGE binding properties increased with the time of heating and the formation of aggregates suggested that the aggregated proteins have higher binding properties to SRAGE which may lead to an increased uptake of glycated proteins/agglomerated by dendritic cells.

In the early stages of the Maillard reaction, moderate glycation has only slight effects on the allergenicity of BLG, whereas after the formation of AGEs in the advanced stages, a clear "masking" effect on the reaction between the allergens and IgE antibodies was observed. ${ }^{35}$ This effect, and the formation of new epitopes ${ }^{55}$ determine the immunogenicity of glycated allergens. We showed the decreased IgG binding to dry-heated 

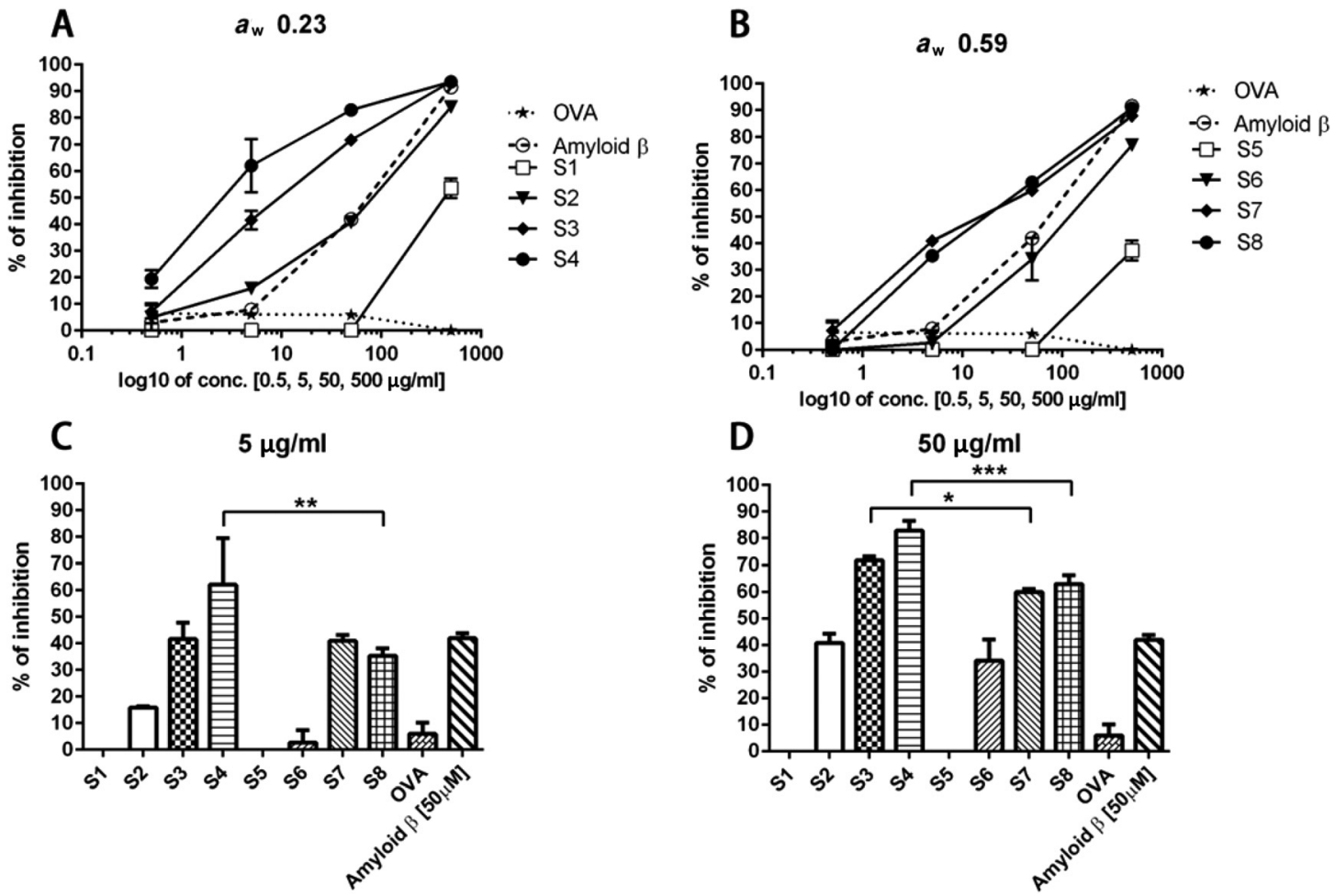

Fig. 6 Inhibition capacity of dry heated samples on RAGE binding. The percentage of inhibition of RAGE binding is presented as a function of the protein concentration of samples with $a_{w} 0.23$ (A) and 0.59 (B). The influence of $a_{w}$ on the formation of AGEs was evaluated in the samples with protein concentration $5 \mu \mathrm{g} \mathrm{m}^{-1}$ (C) and $50 \mu \mathrm{g} \mathrm{ml}^{-1}$ (D). s1, s5: unheated; s2, s6: dry heated for $5 \mathrm{~min}$; s3, s7: dry heated for 10 min; s4, s8: dry heated for $20 \mathrm{~min}$; $\mathrm{s} 1-\mathrm{s} 4 a_{\mathrm{w}} 0.23 ; \mathrm{s} 5-\mathrm{s} 8 a_{\mathrm{w}}$ 0.59. OVA was used as negative control. Amyloid $\beta$ was used as positive control. Data are expressed as mean \pm SD from three independent experiments. ${ }^{*} p<0.05 ;{ }^{* *} p<0.01 ;{ }^{* *} p<0.005$.

whey proteins, however, the formed Maillard reaction products showed a high affinity to the RAGE receptor which may influence their immune response. Besides, the AGEs can also affect the immunogenicity of allergens via activation of key immune cells such as macrophages and dendritic cells. ${ }^{56}$

As heat-treated foods are considered as the main exogenous source of AGEs, the preparation method has attracted serious attention especially in the preparation of infant nutrition. Previous studies have reported that water content, temperature, heating time and $\mathrm{pH}$ are related to the formation of AGEs. ${ }^{21,57}$ In this study, moisture $\left(a_{\mathrm{w}}\right)$ and heating time were both found to significantly affect the production of AGEs and also the formation of sRAGE-binding ligands.

\section{Conclusion}

Intensive dry heating at a lower $a_{\mathrm{w}}(0.23)$ favours the aggregation and Maillard reaction of the samples. Unfolding and aggregation of the whey proteins determined the accessibility of the thiol groups and amino acids, which was also correlated with the stage of the Maillard reaction. As most of the lysine residues are located in the epitope areas of whey proteins, the Maillard reaction between these lysine residues and lactose will result in modifications of the conformational IgG epitopes of whey proteins. The IgG-binding capacity of soluble allergens subsequently decreased during dry heating.

The IgG-binding capacity of the samples heated for $20 \mathrm{~min}$ at $130{ }^{\circ} \mathrm{C}$ is still $67 \%$ of that of unheated proteins. The fact that intensively heated milk can be consumed by most people allergic to cow's milk and can accelerate the resolution of CMA is thus probably not only due to a decrease in the IgG-binding capacity of soluble allergens. The large portion of the remaining insoluble proteins may be also responsible for the induction of immune tolerance to CM allergens, due to the modifications these allergens underwent.

Dry heating promotes the formation of sRAGE-binding ligands, depending on the heating conditions (water activity and heating intensity). The sRAGE-binding capacity correlated positively with the formation of aggregates but negatively with the IgG-binding capacity of the intensively dry-heated samples.

\section{References}

1 A. M. Branum and S. L. Lukacs, Pediatrics, 2009, 124, 15491555.

2 J. M. Skripak, E. C. Matsui, K. Mudd and R. A. Wood, J. Allergy Clin. Immunol., 2007, 120, 1172-1177. 
3 A. H. Lichtenstein, L. J. Appel, M. Brands, M. Carnethon, S. Daniels, H. A. Franch, B. Franklin, P. Kris-Etherton, W. S. Harris and B. Howard, Circulation, 2006, 114, 82-96.

4 J. S. Kim, A. Nowak-Węgrzyn, S. H. Sicherer, S. Noone, E. L. Moshier and H. A. Sampson, J. Allergy Clin. Immunol., 2011, 128, 125-131.e2.

5 A. Nowak-Węgrzyn and H. A. Sampson, J. Allergy Clin. Immunol., 2011, 127, 558-573.

6 A. Thyagarajan, P. Varshney, S. M. Jones, S. Sicherer, R. Wood, B. P. Vickery, H. Sampson and A. W. Burks, J. Allergy Clin. Immunol., 2010, 126, 31.

7 P. Davis, C. Smales and D. James, Allergy, 2001, 56, 56-60.

8 N. Kleber, I. Krause, S. Illgner and J. Hinrichs, Eur. Food Res. Technol., 2004, 219, 105-110.

9 M. Gulzar, S. Bouhallab, R. Jeantet, P. Schuck and T. Croguennec, Food Chem., 2011, 129, 110-116.

10 M. Gulzar, V. Lechevalier, S. Bouhallab and T. Croguennec, J. Food Eng., 2012, 112, 296-303.

11 H. Enomoto, C.-P. Li, K. Morizane, H. R. Ibrahim, Y. Sugimoto, S. Ohki, H. Ohtomo and T. Aoki, J. Agric. Food Chem., 2007, 55, 2392-2398.

12 J. F. Povey, N. Perez-Moral, T. R. Noel, R. Parker, M. J. Howard and C. M. Smales, Biotechnol. Prog., 2009, 25, 1217-1227.

13 M. Besler, H. Steinhart and A. Paschke, J. Chromatogr. B: Biomed. Sci. Appl., 2001, 756, 207-228.

14 R. Sánchez-Monge, C. Blanco, A. D. Perales, C. Collada, T. Carrillo, C. Aragoncillo and G. Salcedo, J. Allergy Clin. Immunol., 2000, 106, 190-195.

15 N. Matsudomi, H. Takahashi and T. Miyata, Food Res. Int., 2001, 34, 229-235.

16 A. Nakamura, K. Watanabe, T. Ojima, D.-H. Ahn and H. Saeki, J. Agric. Food Chem., 2005, 53, 7559-7564.

17 P. Gruber, S. Vieths, A. Wangorsch, J. Nerkamp and T. Hofmann, J. Agric. Food Chem., 2004, 52, 4002-4007.

18 P. Resmini and L. Pellegrino, Int. Chromatogr. Lab., 1991, 6, 7-11.

19 J. W. Nin, A. Jorsal, I. Ferreira, C. G. Schalkwijk, M. H. Prins, H.-H. Parving, L. Tarnow, P. Rossing and C. D. Stehouwer, Diabetes Care, 2011, 34, 442-447.

20 T. Koschinsky, C.-J. He, T. Mitsuhashi, R. Bucala, C. Liu, C. Buenting, K. Heitmann and H. Vlassara, Proc. Natl. Acad. Sci. U. S. A., 1997, 94, 6474-6479.

21 J. Uribarri, S. Woodruff, S. Goodman, W. Cai, X. Chen, R. Pyzik, A. Yong, G. E. Striker and H. Vlassara, J. Am. Diet. Assoc., 2010, 110, 911-916.e12.

22 E. Schleicher, C. Weigert, H. Rohrbach, A. Nerlich, B. Bachmeier and U. Friess, Ann. N. Y. Acad. Sci., 2005, 1043, 343-354.

23 C.-H. Wu, S.-M. Huang, J.-A. Lin and G.-C. Yen, Food Funct., 2011, 2, 224-234.

24 L. J. Sparvero, D. Asafu-Adjei, R. Kang, D. Tang, N. Amin, J. Im, R. Rutledge, B. Lin, A. A. Amoscato and H. J. Zeh, J. Transl. Med., 2009, 7, 17.

25 M. B. Sukkar, M. A. Ullah, W. J. Gan, P. A. Wark, K. F. Chung, J. M. Hughes, C. L. Armour and S. Phipps, Br. J. Pharmacol., 2012, 167, 1161-1176.
26 A. E. Moghaddam, W. R. Hillson, M. Noti, K. H. Gartlan, S. Johnson, B. Thomas, D. Artis and Q. J. Sattentau, J. Allergy Clin. Immunol., 2014, 134, 1453-1456.

27 P. Smith, R. I. Krohn, G. Hermanson, A. Mallia, F. Gartner, M. Provenzano, E. Fujimoto, N. Goeke, B. Olson and D. Klenk, Anal. Biochem., 1985, 150, 76-85.

28 R. G. Newton, Scattering theory of waves and particles, Courier Dover Publications, 1982.

29 G. L. Ellman, Arch. Biochem. Biophys., 1959, 82, 70-77.

30 P. Nielsen, D. Petersen and C. Dambmann, J. Food Sci., 2001, 66, 642-646.

31 S. Chawla, R. Chander and A. Sharma, Food Chem., 2009, 116, 122-128.

32 P. Resmini, Ital. J. Food Sci., 1990, 3, 183.

33 P. Finot, R. Deutsch and E. Bujard, Prog. Food Nutr. Sci., 1981, 345-355.

34 T. Desrosiers, L. Savoie, G. Bergeron and G. Parent, J. Agric. Food Chem., 1989, 37, 1385-1391.

35 A. Taheri-Kafrani, J.-C. Gaudin, H. Rabesona, C. Nioi, D. Agarwal, M. Drouet, J.-M. Chobert, A.-K. Bordbar and T. Haertle, J. Agric. Food Chem., 2009, 57, 4974-4982.

36 C. Li, H. Enomoto, S. Ohki, H. Ohtomo and T. Aoki, J. Dairy Sci., 2005, 88, 4137-4145.

37 H. Enomoto, Y. Hayashi, C. Li, S. Ohki, H. Ohtomo, M. Shiokawa and T. Aoki, J. Dairy Sci., 2009, 92, 3057-3068.

38 L. Cornacchia, C. c. Forquenot de la Fortelle and P. Venema, J. Agric. Food Chem., 2014, 62, 733-741.

39 D. T. Ramonaityte, D. Karklina, P. R. Venskutonis, R. Vokk, R. Verhe, F. K. Lucke, P. Kuka, L. Rukshan and A. Shleikin, In Proceedings of the 3rd Baltic Conference on Food Science and Technology, 2008, pp. 134-138.

40 T. T. Le, B. Bhandari and H. C. Deeth, J. Agric. Food Chem., 2011, 59, 5465-5473.

41 J. Gerrard, P. Brown and S. Fayle, Food Chem., 2003, 80, 35-43.

42 K.-M. Järvinen, P. Chatchatee, L. Bardina, K. Beyer and H. A. Sampson, Int. Arch. Allergy Appl. Immunol., 2001, 126, 111-118.

43 M. Friedman, Nutritional and toxicological consequences of food processing, 1991.

44 C. Svenning, J. Brynhildsvold, T. Molland, T. Langsrud and G. Elisabeth Vegarud, Int. Dairy J., 2000, 10, 699-711.

45 A. Venien, D. Levieux, C. Astier, L. Briand, J.-M. Chobert and T. Haertle, J. Dairy Sci., 1997, 80, 1977-1987.

46 S. Nakamura, M. Ogawa, S. Nakai, A. Kato and D. D. Kitts, J. Agric. Food Chem., 1998, 46, 3958-3963.

47 H. Neuvirth, R. Raz and G. Schreiber, J. Mol. Biol., 2004, 338, 181-199.

48 T. Spiegel, Int. J. Food Sci. Technol., 1999, 34, 523-531.

49 Y. Vissers, M. Iwan, K. Adel-Patient, P. Stahl Skov, N. Rigby, P. Johnson, P. Mandrup Müller, L. Przybylski-Nicaise, M. Schaap and J. Ruinemans-Koerts, Clin. Exp. Allergy, 2011, 41, 1631-1642.

50 A. Bierhaus, P. M. Humpert, M. Morcos, T. Wendt, T. Chavakis, B. Arnold, D. M. Stern and P. P. Nawroth, J. Mol. Med., 2005, 83, 876-886.

51 K. Kierdorf and G. Fritz, J. Leukocyte Biol., 2013, 94, 55-68. 
52 A. M. Schmidt, S. Du Yan, S. F. Yan and D. M. Stern, J. Clin. Invest., 2001, 108, 949.

53 T. Hilmenyuk, I. Bellinghausen, B. Heydenreich, A. Ilchmann, M. Toda, S. Grabbe and J. Saloga, Immunology, 2010, 129, 437-445.

54 G. A. Mueller, S. J. Maleki, K. Johnson, B. K. Hurlburt, H. Cheng, S. Ruan, J. B. Nesbit, A. Pomés, L. L. Edwards and A. Schorzman, Allergy, 2013, 68, 1546-1554.
55 T. Mitsuhashi, H. Vlassara, H. Founds and Y. M. Li, J. Immunol. Methods, 1997, 207, 79-88.

56 B. Moser, D. D. Desai, M. P. Downie, Y. Chen, S. F. Yan, K. Herold, A. M. Schmidt and R. Clynes, J. Immunol., 2007, 179, 8051-8058.

57 T. Goldberg, W. Cai, M. Peppa, V. Dardaine, B. S. Baliga, J. Uribarri and H. Vlassara, J. Am. Diet. Assoc., 2004, 104, 1287-1291. 